\title{
DETECTION, TRANSMISSION, AND EXPRESSION CDNA GROWTH HORMONE GENE (PhGH) OF STRIPPED CATFISH IN F-1 TRANSGENIC AFRICAN CATFISH
}

\author{
Huria Marnis\#, Bambang Iswanto, Romy Suprapto, Imron, and \\ Raden Roro Sri Pudji Sinarni Dewi \\ Research Institute for Fish Breeding, Sukamandi, West Java
}

(Received 11 June 2013; Final revised 4 November 2014; Accepted 10 November 2014)

\begin{abstract}
In previous study, the fast growth transgenic founder of African catfish was produced harboring a growth hormone $(\mathrm{GH})$ gene construct containing a stripped catfish growth hormone $(P h G H)$ cDNA. This study was conducted to investigate transgene $(P h G H)$ transmission and expression in F-1 transgenic African catfish. The transgenic founders (female) were crossed with non-transgenic (male) to produce heterozygous F-1 progeny. PhGH gene was detected in the embryo, larvae, and seed of the transgenic F-1 using PCR method. Expression levels of transgene in embryo and larvae were analyzed using real-time quantitative PCR (qPCR) method. The transgene was detected in embryo, larvae and seed of F-1 transgenic African catfish. Founder could transmit PhGH gene to transgenic F-1 lines in ranged 36\% to 48\%. Expression level of Phgh gene in embryo was higher than that of the larvae; whereas in the embryo was $1.5 \mathrm{x}$ $10^{5}-5.2 \times 10^{5}$ copies or $0.49-9.82$ fold, while in the larvae was $1.1 \times 10^{5}-2.5 \times 10^{5}$ copies or 0.19-5.80 fold.
\end{abstract}

KEYWORDS: African catfish, transgenic, growth hormone, transmission, gene expression

\section{INTRODUCTION}

African catfish is one commodity that has been widely cultivated in Indonesia. Industrial development of African catfish is expected to increase and improve the national fishery products in the future. Improvement of the genetic quality of the seed and broodstock are regarded as an important component to support the achievement of national fish production. It can be done by molecular and biotechnological approaches, one of them by accelerating the growth of fish by the transgenesis method. The application of the transgenesis method in the world's fisheries can improve the charac- ter, such as growth performance, disease resistance, and adaptation to a particular environment (Sarmasik, 2003).

Transgenesis is done by the insertion of genes, gene modification or degradation with the aim of modifying the corresponding organism specific characteristics. These characteristics will be genetically stable since incorporated into the genome of a particular organism and may be passed on the next generation (Carter, 2004). Transgenesis has been successfully carried out to accelerate the growth of fish by introducing the gene encoding growth hormone $(\mathrm{GH})$. GH gene transfer has been ap-

\# Corresponding author. Research Institute for Fish Breeding

J. Raya 2 Sukamandi, Subang 41256, West Java, Indonesia. Telp.: +62 260520500

E-mail: marnis.huria@gmail.com 
plied to several species of fish and proven to increase growth (Nam et al., 2001; Kobayashi et al., 2007).

The research on fast-growing fish using transgenic methods continue to evolve. In addition to the development of transgene integration methods, several studies on genomic integration and germline transmission of the transgene were carried out for transgenic fish. The results showed that the frequency of genomic integration and germline transmission of the transgene were typically only a few percent of each generation (Stuart et al., 1990; Culp et al., 1991; Lin et al., 1999). Transgene can be integrated in the somatic cells and germ cells. The transgene which can be Integrated in the germ cells, will allow to be transmitted to the next generation. Besides the detectable transgene, the transgene should be expressed in the next generation as in embryos, larvae, and seeds (Farlora et al., 2009; Kobayashi et al., 2007; Devlin et al., 2012).

Previous research has been conducted on the introduction of stripped catfish (Pangasionodon hypophtalmus) growth hormone cDNA (pCcBA-PhGH) in African catfish (Clarias gariepinus), using the electroporation method. The founder was expected to inheritance the fast growth characteristics to the first generation (F-1). The transgenic founder have been crossed with non-transgenic to produce heterozygous F-1 progeny. This study aimed to determine the transmission and expression level of transgene.

\section{MATERIALS AND METHOD}

\section{Animal and Sample Collection}

In this study, the pCcBA-PhGH construct (Dewi, 2010) and the transgenic $\left(F_{1}\right)$ African catfish (four months of age) carrying the pCcBA$\mathrm{PhGH}$ construct which were generated by electroporation with $100 \mu \mathrm{g} / \mathrm{mL}$ of the construct (Dewi et al., 2011) were used. All of fish were from a single family of African catfish (Clarias gariepinus) and originated from the collection in the Research Institute for Fish Breeding, Indonesia.

\section{Detection and Distribution $\mathrm{PhGH}$ in Transgenic African Catfish F-1}

\section{DNA Extraction}

PhGH gene detection was performed on 25 embryos pooling, 25 larvae pooling, 255 fry each individual (2 months old), and organs (pituitary, brain, liver, heart, spleen, kidney, intestine, stomach, muscle, thymus, gill, and eye). Genomic DNA of each sample was extracted using DNA extraction kit following the protocols recommended by manufacturer (Genejet Genomic DNA Purification, Thermo Scientific). Briefly, the protocol consist of series of steps including cell lysis, DNA precipitation, binding DNA to the column, washing, and elution. To ensure the success of genomic DNA extraction process, the sample was run on mini horizontal gel electrophoresis. The sample was loaded into the $1.5 \%(\mathrm{w} / \mathrm{v})$ agarose gel, powered with 65 volt electricity and run for 50 minutes. The gel was then stained with ethidium bromide $(0.5 \mu \mathrm{g} / \mathrm{mL})$ and viewed using gel documentation system ultraviolet transillumination.

\section{Polymerase Chain Reaction (PCR)}

Amplification of $\mathrm{PhGH}$ was performed using thermal cycling system (mycycler, Biorad). PCR standard was performed in a final volume of $25 \mu \mathrm{L}$, using a commercial kit master mix fast start PCR master (Roche, Germany). The PCR was used to amplify a 392-bp fragment of $\mathrm{PhGH}$ with primers $P h G H 1$-F (5'-TAG AGT GTT GGT GGT GCT CTC TGT-3') and PhGH2-R (5'-CGA TAA GCA CGC (GA TGC CCA TTT-3'), for 35 cycles: denaturing at $94^{\circ} \mathrm{C}$ for $30 \mathrm{secs}$, annealing at $55^{\circ} \mathrm{C}$ for 30 seconds, and extension at $72^{\circ} \mathrm{C}$ for 1 min. The amplification using the specific primer of $\beta$-actin was performed as internal control. The $\beta$-actin primers:bact- $\mathrm{F}$ (5'-TAT GAA GGT TAT GCT CTG CCC-3') and bact-R (5'-CAT ACC CAG GAA AGA TGG CTG-3') were designed from a catfish growth hormone sequence (Accession JF303887.1). The reaction was incubated at $94^{\circ} \mathrm{C}$ for 30 secs, annealing at $55^{\circ} \mathrm{C}$ for 30 secs, and extension at $72^{\circ} \mathrm{C}$ for $1 \mathrm{~min}$ for $30 \mathrm{cycle}$ and the PCR products were then separated on $1.5 \%(\mathrm{w} / \mathrm{v})$ agarose gel stained with ethidium bromide $(0.5 \mu \mathrm{g} / \mathrm{mL})$ and visualized by ultraviolet transillumination.

\section{Analysis of PhGH Gene Expression Level}

\section{RNA Extraction}

Total RNA was extracted from 25 embryos pooling, 25 larvae pooling, and organs (pituitary, brain, liver, heart, spleen, kidney, intestine, stomach, muscle, thymus, gill, and eye) which were obtained from three transgenic and three non-transgenic fish using animal RNA 
extraction kit following the protocols recommended by manufacturer (Tri Reagent Molecular Research Center, Inc., Cincinnati, OH, USA). Small amount of fresh tissue was homogenized in Tri-Reagent RNA ( $1 \mathrm{~mL}$ per 50-100 mg tissue) followed by incubation for 5 mins at room temperature. $100 \mu \mathrm{L}$ bromochloropropane per 1 $\mathrm{mL}$ Tri Reagent were added, then shaking for 15 secs, incubated for 15 mins at room temperature and spinning $12,000 \times \mathrm{g}$ for $15 \mathrm{mins}$ at $4^{\circ} \mathrm{C}$. The aqueous phase was collected and precipitated with 0.4 volumes of isopropanol, and stored at $4^{\circ} \mathrm{C}$ for $5 \mathrm{~min}$. The precipitated RNA was washed with $1 \mathrm{~mL} 75 \%$ ethanol and resuspended in $200 \mu \mathrm{L}$ RNAsecure (Ambion) and heated at $60^{\circ} \mathrm{C}$ for 10 mins. The total RNA was diluted to $1.0 \mathrm{mg} / \mathrm{mL}$ in RNase-free water and photospectrometrically quantified at $A_{260}$. Purity of total RNA was assessed by the 260 / $280 \mathrm{~nm}$ ratio (between 1.8 and 2.1). For synthesizing $1^{\text {st }}$-strand $\mathrm{cDNA}, 50 \mu \mathrm{g}$ of total RNA was treated with commercial kit CDNA ReadyTo-Go ${ }^{\text {TM }}$ RT-PCR Beads (GE Healthcare) according to the protocol suggested by the manufacturer and 1 Oligo $\mathrm{d}(\mathrm{T})_{16}$ primer (Roche, Germany) in a final volume of $33 \mu \mathrm{L}$. cDNA concentration was always determined with gene Quant (Qiagen), which was more accurate than spectrophotometric determination (OD260/280).

\section{Real-Time PCR Analysis}

The RT-PCR was performed to detect $\mathrm{PhGH}$ gene expression in 25 pooled embryos, 25 pooled larvae and pituitary, brain, liver, heart, spleen, kidney, intestine, stomach, muscle, gill, thymus, and eye organs. The qPCR was conducted with $100 \mathrm{ng}$ DNA duplicate in a $25 \mu \mathrm{L}$ reaction. Real-time PCR was performed using Rotor-Gene SYBR Green kit (Qiagen) and the Rotor Gene Real-Time PCR System (Qiagen), with the following parameters: $95^{\circ} \mathrm{C}$ for 10 secs, followed by 40 two steps cycles at $95^{\circ} \mathrm{C}$ for 5 secs and at $60^{\circ} \mathrm{C}$ for 30 secs. The $\mathrm{PhGH}-\mathrm{F}$ and $\mathrm{PhGH} 2-\mathrm{R}$ primers were used. The $\beta$-actin gene was used as a reference gene. The sizes of the amplification products were $392 \mathrm{bp}$ for the $\mathrm{PhGH}$ gene and $300 \mathrm{bp}$ for the $\beta$-actin gene. For each cDNA sample always amplified independently on the same plate and in the same experimental was run in triplicate. The melting curve analysis showed that all reactions were free of primer-dimers or other non-specific products (data not shown). In order to examine the PhGH copy number, generation of the absolute quantitative standard curve was necessary. First, a series of standard samples con- taining $3 \times 10^{1}, 3 \times 10^{2}, 3 \times 10^{3}, 3 \times 10^{4}$ copies of plasmid pCcBA-PhGH were prepared. The copies number values were calculated by the Rotor-gene Q software (Qiagen).

\section{Data Analysis}

Data were analyzed descriptively and statistically. Descriptive analysis was conducted for detection and expression of PhGH gene, and presented as means \pm SD. Statistical analysis using the Student's t-confidence interval of $95 \%$ was performed for expression of $\mathrm{PhGH}$ gene.

\section{RESULTS AND DISCUSSION}

Total of 56 positive transgenic founders carried the transgene $(\mathrm{PhGH})$ in the caudal fin, only 9 individuals (10.71\%) have been carried the transgene in the gonad. The founders that carrying transgene in gonads have been used to generate transgenic African catfish F-1 generation (Figure 1, Table 1). Recent studies have shown that the four founders which carried transgene in the caudal fin were produced by microinjection method, only one founder carried the transgene in sperm (Hinit \& Moav, 1999). Later, Rahman \& Maclean (1999) observed that 118 positive male tilapia fish carried the transgene on the caudal fin; only seven fish carried transgene in the sperm.

\section{Detection of PhGH Gene in Catfish F-1 Generation}

$\mathrm{PhGH}$ gene was detected in all embryos and larvae of six pairs of founders (Figure 2). This indicates that $P h G H$ gene could be transmitted from all founders to offspring (Table 2 ). The results of this study were similar to those reported by Lin et al. (1999) almost all founders could transmit the transgene to the next generation.

Founder could transmit PhGH gene to F- 1 transgenic lines in ranged $36 \%$ to $48 \%$ (Table 2 ), indicating that the individual containing the transgene in only a part of their germ cell. Liang et al. (2000) have demonstrated that, germline transmission of transgenes in F-1 transgenic lines in ranged $18.2 \%$ to $55.5 \%$. Figueiredo et al. (2007) have also demonstrated transmission of transgenes from founder to F-1 generation in zebrafish in ranged $2.2 \%$ to $42 \%$. These results indicate that, all founders could transmit the transgene to offspring (Table 2). In contrast Stuart et al. (1988), reported that 20 


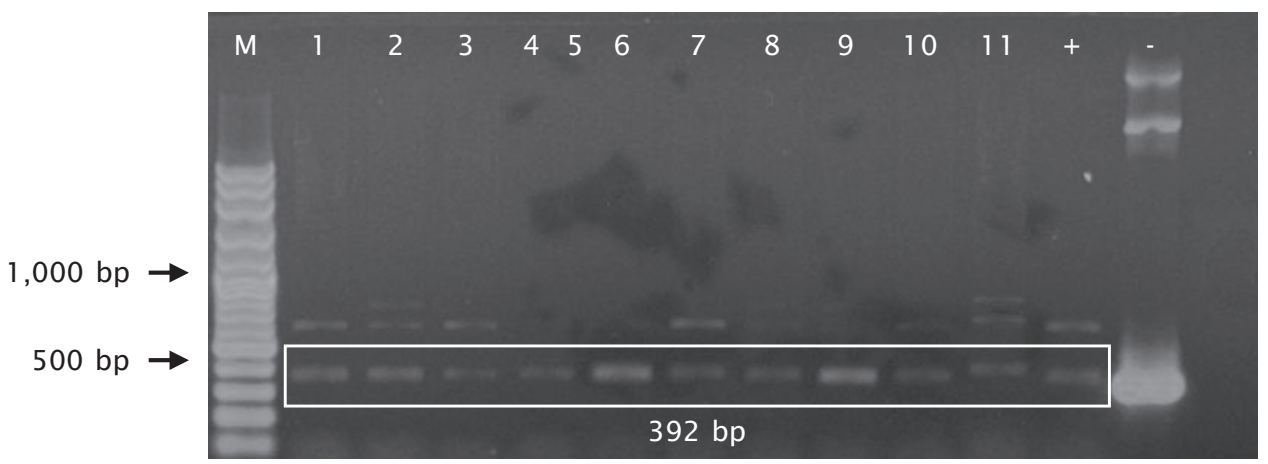

Figure 1. Detection of $P h G H$ gene in caudal fin and ovum from six of transgenic founder (F-0). Lane 1-5 = Caudal fin sample from founder and lane 6-1 1 = Eggs sample. $M$ indicates a DNA marker (100-3,000 bp) (vivantis). (+) positif control (pCcBA-PhGH). (-) negative control. The expected size of $P h G H$ gene was $392 \mathrm{bp}$

Table 1. Percentage of founders carrying $\mathrm{PhGH}$ gene in caudal fin and gonad

\begin{tabular}{ccc}
\hline \multirow{2}{*}{ Founder } & \multicolumn{2}{c}{ Percentage of founders which have carried $\boldsymbol{P h}$ GH gene in } \\
\cline { 2 - 3 } & Caudal fin & Gonads \\
\hline Female & $56.00 \%(56 / 100)$ & $10.71 \%(6 / 56)$ \\
\hline
\end{tabular}
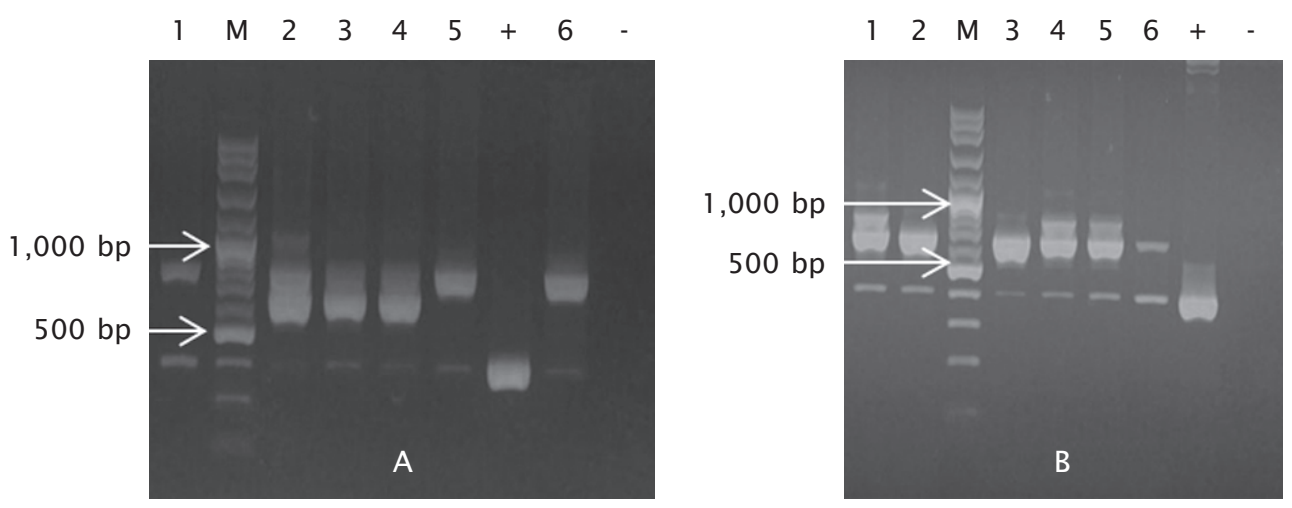

Figure 2. Detection $\mathrm{PhGH}$ in embryo from catfish F-1 (A) and detection $\mathrm{PhGH}$ in larvae from catfish F-1 (B). Lane (1-6) samples. M indicates a DNA marker (100-3,000 bp) (vivantis). (+) positif control (pCcBA-PhCH). (-) negative control. The expected size of $\mathrm{PhGH}$ gene amplification product is $392 \mathrm{bp}$

founder transgenic zebrafish were crossed with wild-type, only one founder could transmit transgene to the first generation. Rahman $\&$ Maclean (1999) have also reported that of the 13 founders tilapia were crossed to generate the F-1 generation, only three founders could transmit the transgene in the offspring with the percentage of transgene transmission in ranged $1 \%$ to $8 \%$.

\section{Analysis of Gene Expression in Embryos and Larvae PhGH Catfish F-1 Generation Transgenic}

Transgene could be expressed in all embryos and larvae of the six parents. Transgene expression level ranged from $1.5 \times 10^{5}$ to $5.2 \times$ $10^{5}$ copies in the embryos and $1.1 \times 10^{5}$ to 2.5 $\times 10^{5}$ copies in the larvae (Figure $3 \mathrm{~A}$ and $\mathrm{B}$ ). 


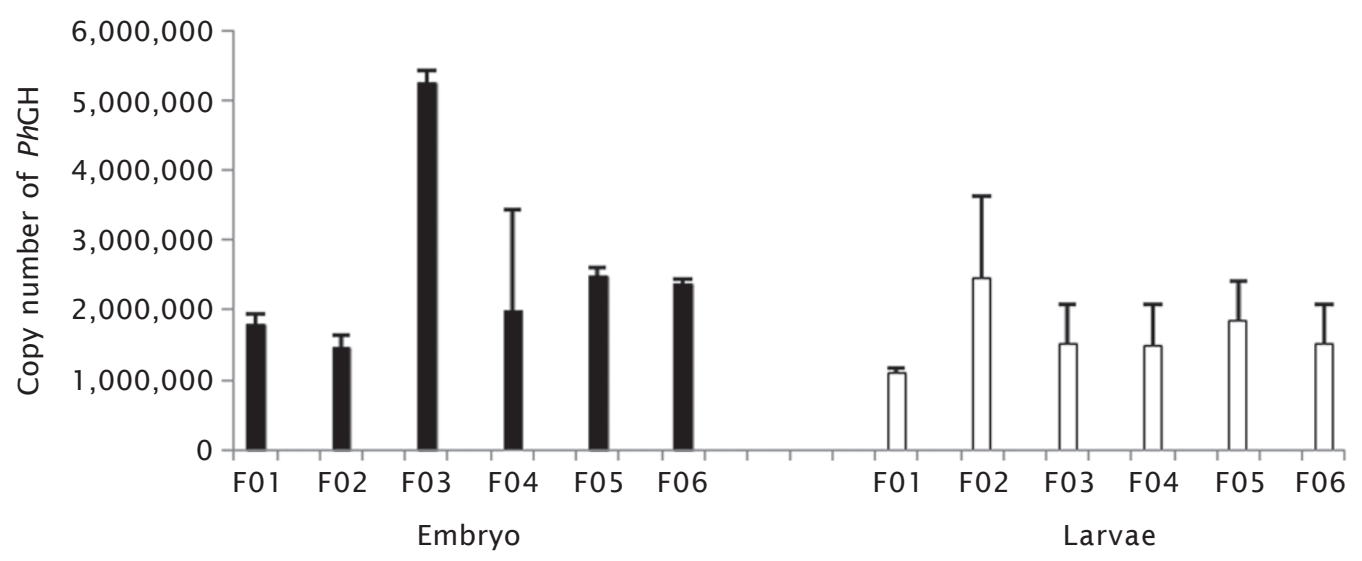

Figure 3. PhGH gene expression level in embryo and larvae of F-1 transgenic African catfish analyzed by of quantitative RT-PCR. Vertical bars represent standard deviation $(n=3)$

Table 2. Transmission of transgene in African catfish F-1 population

\begin{tabular}{cc}
\hline $\begin{array}{c}\text { Transgenic } \\
\text { founder }\end{array}$ & $\begin{array}{c}\text { Percentage trans- } \\
\text { mission transgene }\end{array}$ \\
\hline F01 & $(50 / 22) 44$ \\
F02 & $(50 / 20) 40$ \\
F03 & $(50 / 24) 48$ \\
F04 & $(25 / 9) 36$ \\
F05 & $(25 / 2) 8$ \\
F06 & $(25 / 9) 36$ \\
\hline Average & 38.22 \\
\hline
\end{tabular}

Transgene expression levels in each F-1 embryos and larvae varied. Level of transgene expression in embryos was higher than in larvae. The different expression was sometimes attributed to the use of promoter sequences from very distantly related species. Expression of $\mathrm{GH}$ transgenes has been documented (Devlin et al., 1995). Transgene expression in embryos and larvae also influenced by the carp $\beta$-actin promoter used in this study. Such research has been reported by Moav et al. (1992), $\beta$-actin promoter carp showed strong expression in common carp. $\beta$-Actin is an abundant protein in virtually all cell types and is very active promoter. Strong expression in zebrafish embryos has been identified by using $\beta$-actin promoter homolog (Higashijima et al., 1997). More recently, a study reported by Farlora et al. (2009), that the transgene could be expressed strongly in transgenic tilapia larvae at 10 days age after fertilazation using Japanese medaka $\beta$-actin promoter.

Furthermore, Inoue et al. (1990) reported that, the level of transgene expression varied among individual transgenic, due to variations of the copy number and different site integration in individuals. In addition, the average difference between the levels of expression caused by differences of number individuals carrying the transgene, it is necessary to test transgene expression per individual. Expression of PhGH has been controlled by $\beta$-actin promoter. $\beta$-actin promoter can be active in all tissue and it does not need out induction. No PhGH signal observed with cDNA from tissue of non-transgenic (controls).

\section{CONCLUSION}

The PhGH gene can be detected and transmited from the founder ( $F-0)$ to the first generation $(\mathrm{F}-1)$ with a transmission rate of $38.22 \%$. PhGH gene can also be detected and expressed in embryos and larvae. PhGH level of gene expression in embryos was higher than in larvae.

\section{REFERENCES}

Butler, A., \& LeRoith, D. (2001). Minireview: tissue-specific versus generalized gene targeting of the igf 1 and igf $1 r$ genes and their roles in insulin-like growth factor physiology. Endocrinology, 142, 1685-1688.

Caelers, A., Maclean, N., Hwang, G., Eppler, E., $\&$ Reinecke, M. (2005). Expression of endogenous and exogenous growth hor- 
mone $(\mathrm{GH})$ messenger mRNA in a $\mathrm{H}$ transgenic tilapia (Oreochromis niloticus). Transgenic Res., 14(1), 95-104.

Cheng, C.A., Lu, K.L., Lau, E.L., Yang, T.Y., Lee, C.Y., Wu, J.L., \& Chang, C.Y. (2002). Growth promotion in ayu (Plecoglossus altivelis) by gene transfer of the rainbow trout growth hormone gene. Zool. Stud., 41 (3), 303-310.

Cole, A.M., Darouiche, R.O., Legarda, D., Connell, N., \& Diamond, G. (2000). Characterization of a fish antimicrobial peptide: gene expression, subcellular localization, and spectrum of activity. Antimicrobial Agents and Chemotherapy, 44, 2039-2045.

Cook, J.T., McNiven, M.A., Richardson, G.F., \& Sutterlin, A.M. (2000). Growth rate, body composition and feed digestibility/conversion of growth enhanced Atlantic salmon (Salmo salar). Aquaculture, 188, 15-32.

Devlin, R.H., Yesaki, T.Y., Donaldson, E.M., \& Hew, C.L. 1995. Transmission and phenotypic effects of an antifreeze/GH gene construct in coho salmon (Oncorhynchus kisutch). Aquaculture, 137, 161-169.

Devlin, R.H., Swanson, P., Clarke, W.C., Plisetskaya, E., Dickhoff, W., Moriyama, S., Yesaki, T.Y., \& Hew, C.L. (2000). Seawater adaptability and hormone levels in growthenhanced transgenic coho salmon, Oncorhynchus kisutch. Aquaculture, 191, 367385.

Devlin, R.H., Biagi, C.A., \& Yesaki, T.Y. (2004). Growth, viability and genetic characteristics of $\mathrm{GH}$ transgenic coho salmon strains. Aquaculture, 236, 607-632.

Devlin, R.H., Vandersteen, W.E., Uh, M., \& Stevens, E.D. (2012). Genetically modified growth affects allometry of eye and brain in salmonids. Canadian Journal of Zoology, 90(2), 193-202.

Dewi, R.R.S.P.S. (2010). Studies over-expression of the growth hormone gene by electrophoresis sperm to create transgenic Siamese catfish grow faster. Dissertation. $75 \mathrm{pp}$.

Douglas, S.E., Gallant, J.W., Gong, Z., \& Hew, C. (2001). Cloning and developmental expression of a family of pleurocidin-like antimicrobial peptides from winter flounder, Pleuronectes americanus (Walbaum). Developmental and Comparative Immunology, 25, 137-147.

Du, S.J., Gong, Z., Fletcher, G.L., Shears, M.A., King, M.J., Idler, D.R., \& Hew, C.L. (1992). Growth enhancement in transgenic Atlan- tic salmon by the use of an "all fish" chimeric growth hormone gene construct. Biol. Tech., 10, 176-180.

Eppler, E., Caelers, A., Shved, N., Hwang, G., Rahman, A.M., Maclean, N., Zapf, J., \& Reinecke, M. (2007). Insulin-like growth factor I (IGF-I) in a growth-enhanced transgenic (GH-overexpressing) bony fish, the tilapia (Oreochromis niloticus): indication for a higher impact of autocrine/paracrine than of endocrine IGF-I. Transgenic Res., 16, 479489.

Farlora, R., Kobayashi, S., França, L.R., Batlouni, S.R., Lacerda, S.M.S.N., \& Yoshizaki, G. (2009). Expression of GFP in transgenic tilapia under the control of the medaka $\beta$ actin promoter: establishment of a model system for germ cell transplantation. Anim. Reprod, 6(3), 450-459.

Fletcher, G.L., Hobbs, R.S., Evans, R.P., Shears, M.A., Hahn, A.L., \& Hew, C.L. (2011). Lysozyme transgenic Atlantic salmon (Salmo salar L.). Aquaculture Research, 42, 427-440.

Figueiredo, M.A., Lanes, C.F.C., \& Almaida, D.V. (2007). Improving the production of transgenic fish germlines: In vivo evaluation of mosaicism in zebrafish (Danio rerio) using a green fluorescent protein (GFP) and growth hormone cDNA transgene co-injection strategy. Genetics and Molecular Biology, 30(1), 31-36.

Guan, B., Ma, H., Wang, Y., Hu, Y., Lin, Z., Zhu, Z., \& Hu, W. (2011). Vitreoscilla hemoglobin (VHb) over expression increases hypoxia tolerance in zebrafish (Danio rerio). Marine Biotechnology, 13, 336-364.

Hallerman, E.M., McLean, E., \& Fleming, I.A. (2007). Effects of growth hormone transgenes on the behavior and welfare of aquacultured fishes: a review identifying research needs. Applied Animal Behaviour Science, 104, 265-294.

Hew, C.L., Fletcher, G.L., \& Davies, P.L. (1995). Transgenic salmon: tailoring the genome for food production. J. Fish Biol., 47, 1-19.

Higashijima, S., Okamoto, H., Ueno, N., Kurihara, Y., Schartl, A., \& Eguchi, G. (1997). High frequency generation of transgenic zebrafish which reliably express GFP in whole muscles or the whole body by using promoters of zebrafish origin. Dev. Biol., 192, 289-299.

Hinit, Y., \& Moav B. (1999). Growth performance studies in transgenic Cyprinus carpio. 
Aquaculture, 173, 285-296.

Hu, W., \& Zhu, Z.Y. (2010). Integration mechanisms of transgenes and population fitness of GH transgenic fish. Science China. Life Sciences, 53, 401-408.

Inoue, K., Yamashita, S., Hata, J., Kabeno, S., Asada, S., Nagahisa, E., \& Fujita, T. (1990). Electroporation as a new technique for producing transgenic fish. Cell. Differ. Dev., 29, 123-128.

Kobayashi, S., Alimuddin, Morita, T., Miwa, M., Lu, J., Endo, M., Takeuchi, T., \& Yoshizaki, G. (2007). Transgenic nile tilapia (Oreochromis niloticus) over expressing growth hormone show reduced ammonia excretion. Aquaculture, 270, 427-435.

Liang, M., Alestrom, R., \& Collas, P. (2000). Glowing zebrafish: integration, transmission, and expression of a single luciferase transgene promoted by noncovalent DNAnuclear transport peptide complexes. Mol. Reprod. Dev., 55, 8-13.

Lin, S., Yang, S., \& Hopkins, N. (1994). lacZ expression in germline transgenic zebrafish can be detected in living embryos. Dev. Biol., 161, 77-83.

Lu, J.K., Fu, B.H., Wu, J.L., \& Chen, T.T. (2002). Production of transgenic silver sea bream (Sparus sarba) by different gene transfer methods. Mar. Biotechnol., 4, 328-337.

Moriyama, S., Ayson, F.G., \& Kawauchi, H. (2000). Growth regulation by insulin-like growth factor-I in fish. Biosci. Biotechnol. Biochem., 64, 1553-1562.

Maov, W.F., Wang, Y.P., Wang, W.B., Bo, W., Feng, J.X., \& Zhu, Z.Y. (2004). Enhanced resistance to Aeromonas hydrophila infection and enhanced phagocytic activities in human lactoferrin-transgenic grass carp (Ctenopharyngodon idellus). Aquaculture, 242, 93-103.

Merino, G., Barange, M., Blanchard, J.L., Harle, J., Holmes, R., Allen, I., Allison, E.H., Badjeck, M.C., Dulvy, N.K., Holt, J., Jennings, S., Mullon, C., \& Rodwell, L.D. (2012). Can marine fisheries and aquaculture met fish demand from a growing human population in a changing climate?. Elsevier, Global Environmental Change, 22, 795-806.

Nam, Y.K., Noh, J.K., Cho, Y.S., Cho, H.J., Cho, K.N., Kim, C.G., \& Kim, D.S. (2001). Dramatically accelerated growth and extraordinary gigantism of transgenic mud loach Misgurnus mizolepis. Transgenic Research, 10, 353-362.
Pierce, A.L., Beckman, B.R., Shearer, K.D., Larsen, D.A., \& Dickhoff, W.W. (2001). Effects of ration on somatotropic hormones and growth in coho salmon. Comp. Biochem. Physiol. B Biochem. Mol. Biol., 128, 255-264.

Pierce, A.L., Shimizu, M., Beckman, B.R., Baker, D.M., \& Dickho, V.W.W. (2005). Time course of the GH/IGF axis response to fasting and increased ration in chinook salmon (Oncorhynchus tshawytscha). Gen. Comp. Endocrinol., 140, 192-202.

Rahman, M.A., \& Maclean, N. (1999). Growth performance of transgenic tilapia containing an exogenous piscine growth hormone gene. Aquaculture, 173, 333-346.

Raven, P.A., Uh, M., Sakhrani, D., Beckman, B.R., Cooper, K., Pinter, J., Leder, E.H., Silverstein, J., \& R.H. Devlin. (2008). Endocrine effects of growth hormone over expression in transgenic coho salmon. General and Comparative Endocrinology, 159, 26-37.

Saera-Vila, A., Calduch-Giner, J.-A., \& PerezSanchez, J. (2005). Duplication of growth hormone receptor (GHR) in fish genome: gene organization and transcriptional regulation of GHR type I and II in gilthead sea bream (Sparus aurata), Gen. Comp. Endocrinol., 142, 193-203.

Shimizu, M., Swanson, P., \& Dickhoff, W.W. (1999). Free and protein-bound insulin-like growth factor-I (IGF-I) and IGF-binding proteins in plasma of coho salmon, Oncorhynchus kisutch. Gen. Comp. Endocrinol., 3, 398-405.

Spadafora, C. (2008). Sperm-mediated 'reverse' gene transfer: a role of reverse transcriptase in the generation of new genetic information. Mini review development reproductiv biologi and medicine. Human Reproduction, 10, 735-740.

Tsai, H.J. (2000). Electroporated sperm mediation of a gene transfer system for finfish and shellfish. Mol. Repro. Dev., 56, 281-284.

Very, N.M., Kittilson, J.D., Norbeck, L.A., \& Sheridan, M.A. (2005). Isolation, characterization, and distribution of two cDNAs encoding for growth hormone receptor in rainbow trout (Oncorhynchus mykiss), Comp. Biochem. Physiol. Part B: Biochem. Mol. Biol., 140, 615-628.

Zhong, J.Y., Wang, Y.P., \& Zhu, Z.Y. (2002). Introduction of the human lactoferrin gene into grass carp (Ctenopharyngodon idellus) to increase resistance against GCH virus. Aquaculture, 214, 93-101. 